\title{
Enzymatic Characterization of Recombinant Cyclodextrin Glycosyltransferase from Bacillus sp. A2-5a using Sagoo Starch as Substrate
}

\author{
RINA IMANIAR ${ }^{1}$, CATUR RIANI $^{1}$, DESSY NATALIA $^{2}$, \\ AND DEBBIE SOFFIE RETNONINGRUM ${ }^{1 *}$
}

\author{
'School of Pharmacy, Institut Teknologi bandung, Jalan Ganesha 10, Bandung 40132, Indonesia; \\ ${ }^{2}$ Faculty of Mathematics and Science, Institut Teknologi bandung, Jalan Ganesha 10, Bandung 40132, Indonesia
}

\begin{abstract}
Cyclodextrin $(\mathrm{CD})$ is a cyclic oligosaccharide molecule and depending on the number of glucose molecules, three types of CDs are commonly used, $\alpha-C D, \beta-C D$, and $\gamma-C D$. CDs can be produced enzymatically using starch as substrate catalyzed by CD glycosyltransferase (CGTase). In current research, recombinant CGTase production from the synthetic gene was optimized for its production using three growth media and two induction temperatures. The highest yield was obtained in Luria Bertani medium at $25{ }^{\circ} \mathrm{C}$. The rCGTase protein was affinity purified as a $76.39 \mathrm{kDa}$ protein which showed $\beta$-cyclization and starch hydrolysis activities using zymography method. The optimum temperature, $\mathrm{pH}$, and incubation time was $55^{\circ} \mathrm{C}, 6$, and $24 \mathrm{~h}$, respectively. The enzyme was stable at a wide $\mathrm{pHs}$ in the range of 5-10, retained its half activity at $56^{\circ} \mathrm{C}$ for $30 \mathrm{~min}$ and had cyclization ratio for $\alpha$-CD: $\beta$-CD: $\gamma$-CD was $4: 81: 15$. An amount of $542 \mathrm{mg} \beta$-cyclodextrin was produced from $100 \mathrm{~mL}$ reaction of $1 \%(\mathrm{~b} / \mathrm{v})$ sagoo starch using $38.4 \mu \mathrm{g}$ rCGTase in optimum condition. This work reports for the first time the character of rCGTase from Bacillus sp. A2-5a using sagoo starch as a substrate.
\end{abstract}

Key words: Bacillus sp. A2-5a, $\beta$-cyclodextrin, characterization, rCGTase, sagoo starch

Siklodekstrin (CD) merupakan molekul oligosakarida siklik. Berdasarkan jumlah molekul glukosa yang dikandungnya, tiga tipe $C D$ yang biasa digunakan yaitu $\alpha-C D, \beta-C D$, dan $\gamma-C D$. CD dapat diproduksi melalui konversi enzimatik pati menggunakan siklodekstrin glikosiltransferase (CGTase). Pada penelitian ini dilakukan optimasi jenis medium dan suhu induksi yang digunakan untuk produksi CGTase rekombinan dari gen sintetik. Rendemen rCGTase tertinggi didapatkan dengan penggunaan medium Luria Bertani (LB) pada suhu $25^{\circ} \mathrm{C}$. Protein rCGTase dimurnikan menggunakan kolom afinitas dan menghasilkan protein berukuran 76,39 kDa yang menunjukkan aktifitas siklisasi- $\beta$ dan hidrolisis dengan metode zimografi. Suhu, $\mathrm{pH}$, dan waktu inkubasi optimum aktivitas rCGTase berturut-turut adalah $55^{\circ} \mathrm{C}$, 6, dan 24 jam. Enzim memiliki stabilitas pada rentang pH 5,0-10,0 dan mempertahankan $50 \%$ aktivitasnya pada $56^{\circ} \mathrm{C}$ selama 30 menit. Rasio siklisasi $\alpha-\mathrm{CD}, \beta-\mathrm{CD}$, dan $\gamma$-CD pada penggunaan pati sagu berturut-turut adalah $4: 81: 15$. CD sebanyak 542 mg dihasilkan dari 100 $\mathrm{mL}$ reaksi antara pati sagu $1 \%(\mathrm{~b} / \mathrm{v})$ terpregelatinasi dengan 38,4 $\mu \mathrm{g}$ rCGTase pada kondisi optimum. Penelitian ini melaporkan untuk pertama kali karakter rCGTase dari Bacillus sp. A2-5a dengan pati sagu sebagai substrat.

Kata kunci: Bacillus sp. A2-5a, karakterisasi, pati sagu, rCGTase, siklodekstrin- $\beta$

Cyclodextrin (CD) is a cyclic oligosaccharides enzymatically derived from starch. Three kinds of CD have been identified, namely $\alpha-\mathrm{CD}, \beta-\mathrm{CD}$ and $\gamma-\mathrm{CD}$ which consists of six, seven, eight glucose molecules, respectively (Endo and Ueda 2004). In the CD molecules, glucopyranose units are linked by 1,4 glycosidic bonds which are unique characteristic of linier starch molecule. CD forms a structure with hydrophilic property at outer surface and hydrophobic property at inner cavity, which makes $\mathrm{CD}$ is used for many applications, such as in food, chemistry, pharmacy, analytical, diagnostics, cosmetics and agriculture (Szejtli 1997). It works by trapping the non polar molecule with suitable size through non covalent

*Corresponding author; Phone: +62-22-2504825, E-mail: retnoningrum@indo.net.id interaction. Amongst the three CD molecules, $\beta-C D$ has been used mostly at industrial scale due to its inner cavity size which is more suitable for many applications.

Due to the need of $\mathrm{CD}$ at industrial level, cyclodextrin glycosyltranferase (CGTase, EC 2.4.1.19) has been studied for many years. CGTase is an extracellular enzyme that converts starch and $\beta$ glucan with 1,4 glycosidic bonds to CD. CGTase belongs to family 13 glycoside hydrolase. CGTase that catalyzes the conversion of starch to $\mathrm{CD}$ with $\beta-\mathrm{CD}$ as main products is called $\beta$-CGTase. The $\beta$-CGTase gene from Bacillus sp. A2-5a with accession number of AB015670 (GenBank, NCBI) has been cloned and expressed in Bacillus subtilis ANA-1 (Ohdan et al. 2000). The CGTase gene has 2115 bp which encodes a 704 amino acids preprotein (Accession number 
BAA31539, GenBank, NCBI) with the first 29 amino acids predicted as a signal sequence. The native CGTase has an optimal $\mathrm{pH}$ of 5.5 and an optimal temperature of $50-55{ }^{\circ} \mathrm{C}$ with product specificity of CD- $\alpha: \beta: \gamma$ with ratio of $5: 77: 18$ and the conversion rate was $50 \%$ from soluble starch (Kelly et al. 2009; Ohdan et al.2000).

In our previous research, the CGTase gene of Bacillus sp. A2-5a was codon optimized for high level expression in Escherichia coli and synthetically constructed. Sagoo starch was the best substrate in an assay using Horikoshi medium. This research was aimed to optimize the rCGTase overproduction and characterize the enzyme using sagoo starch as substrate.

\section{MATERIALS AND METHODS}

Bacterial Strain and Growth Condition. E. coli BL21(DE3)/pJExpress_401_cgtase (www.dna20.com) was grown in Luria Bertani (LB) medium containing 25 $\mu \mathrm{g} \mathrm{mL}{ }^{-1}$ kanamycin at $37^{\circ} \mathrm{C}$. All experiments were done using sagoo starch from Riau Island, Indonesia as substrate.

Overproduction and Purification. Three growth media, namely Luria Bertani (LB), Terrific Broth (TB) and Super Optimum Broth (SOB) were used to overproduce rCGTase at two temperatures, 16 and 25 ${ }^{\circ} \mathrm{C}$, in the presence of $0.1 \mathrm{mM}$ of IPTG for $6 \mathrm{~h}$. The rCGTase was affinity purified using resin in column contain nickel and Tris (carboxymethyl) Ethilene Diamine (TED) (Protino, Germany). First, the column was equilibrated with 4 bed volumes of lysisequilibration-wash buffer, then allow the column to drain by gravity. The supernantant was added to the pre equilibrated column and allow the column to drain by gravity. The column was washed twice with 4 bed volumes of lysis-equilibration-wash (LEW) Buffer and allow column to drain by gravity. The rCGTase was eluted in for fractions. Elution was done by the addition of $4 \times 3$ bed volumes of Elution Buffer containing $250 \mathrm{mM}$ imidazole, $\mathrm{pH} 8$ and fractions were collected separately. The overproduction and purification processes were monitored by $10 \%$ SDSPAGE analysis. rCGTase was separated on $10 \%$ polyacrilamide gels for 60 minutes at $125 \mathrm{~V}$. The gel was flooded by Coomassie blue staining and destained with destaining solution to visualize rCGtase band on gel. The concentration of rCGtase was determined by densitometry method compared to Bovine Serum Albumin (BSA) concentration using ImageJ
(Gallagher 2010). The purified rCGTase was used in the enzyme characterization.

Activity Assays. The hydrolysis and cyclization activity were monitored by zymography (Pakzad et al. 2004). Native PAGE was performed with $10 \%$ polyacrylamide gels. Three wells were used to separate $10 \mu \mathrm{LrCGTase}$ each. One half of the gel was incubated in $3 \%$ soluble starch at $37^{\circ} \mathrm{C}$ for $30 \mathrm{~min}$. The gel was washed with distilled water, and stained with a solution containing $0.1 \% \mathrm{I}_{2}$ in $1 \% \mathrm{KI}$. The clear band in the blue context of the gel was indicated of amylolytic activity. For phenolphthalein indicator gel method, the indicator gel was prepared by mixing 0.24 $\mathrm{g}$ soluble starch, $0.14 \mathrm{~g}$ agar in $16 \mathrm{~mL}$ of $0.2 \mathrm{M}$ phosphate buffer ( $\mathrm{pH} 8$ ). After the mixture, $0.5 \mathrm{~mL}$ of $0.4 \%$ phenolphthalein was added and the whole mixture was cooled about $50^{\circ} \mathrm{C}$. The indicator gel was poured on the second half of the polyacrylamide gel. After a 5 min incubation at $37^{\circ} \mathrm{C}$, the indicator gel was flooded with a $0.1 \%$ sodium carbonate solution until the context of the gel turned into red. After visualization of $\beta$-CGTase activity, the third half polyacrylamide gel was subjected to conventional Coomassie blue staining method.

The $\beta$-cyclization activity of rCGTase was measured by spectrophotometer using phenolphtalein method (Goel and Nene 1995). The reaction mixtures containing $1 \%(\mathrm{w} / \mathrm{v})$ gelatinized sagoo starch in various pHs. rCGTase of $0.384 \mu \mathrm{g}$ was incubated at various temperatures for $30 \mathrm{~min}$ at temperature and $\mathrm{pH}$ as described below. The $\beta-\mathrm{CD}$ concentration was measured based on the decrease in color intensity of phenolphtalein at $550 \mathrm{~nm}$.

Optimum Temperature and Thermostability. The optimum temperature of purified rCGtase was determined by incubating 0.02 unit activity (UA) rCGtase with $1 \%(\mathrm{w} / \mathrm{v})$ gelatinized sagoo starch in 50 $\mathrm{mM}$ Tris- $\mathrm{Cl} \mathrm{pH} 6.0$ at different temperatures, ranging from $26-80{ }^{\circ} \mathrm{C}$ for $30 \mathrm{~min}$ and the reaction was stopped using $1.2 \mathrm{M} \mathrm{HCl}$. The gelatinized sagoo starch was prepared by heating sagoo starch suspension at $80^{\circ} \mathrm{C}$ for $15 \mathrm{~min}$. Before the $\beta-C D$ was measured, the reaction was neutralized using $1.2 \mathrm{M} \mathrm{NaOH}$. The reactions were carried out using the rCGtase assay procedure mentioned above (Goel and Nene 1995). The temperature stability of the enzyme was measured by incubating $0.02 \mathrm{UA} \mathrm{rCGtase}$ with an equal volume of 50 $\mathrm{mM}$ Tris-Cl buffer ( $\mathrm{pH}$ 7.0) for $30 \mathrm{~min}$, followed by incubation with $1 \%(\mathrm{w} / \mathrm{v})$ gelatinized sagoo starch for 30 min. Residual activities were measured with the standard assay as mentioned above (Goel and Nene 1995). 
Optimum pH and pH Stability. Three buffers were used to characterize optimum $\mathrm{pH}$ and $\mathrm{pH}$ stability. As the enzyme activity can be different depending on the buffer system, normalization process is necessarily required. The optimum $\mathrm{pH}$ of the purified rCGTase was determined by reacting 0.029 UA enzyme with $1 \%$ $(\mathrm{w} / \mathrm{v})$ gelatinized sagoo starch in various $\mathrm{pHs}, \mathrm{pH} 4$ and 5 using $50 \mathrm{mM}$ sodium acetate buffer, phosphate buffer (pH 6-8) and glycine- $\mathrm{NaOH}$ buffer (9-10) at optimum temperature for $30 \mathrm{~min}$. The reactions were stopped by boiling for $5 \mathrm{~min}$ then neutralized by $75 \mathrm{mM} \mathrm{NaOH}$ for acid condition and $75 \mathrm{mM} \mathrm{HCl}$ for base condition. Then, the subsequent steps were done according to the rCGTase assay described above (Goel and Nene 1995). The $\mathrm{pH}$ stability of the rCGtase was measured by incubating 0.029 UA enzyme at various $\mathrm{pHs}(4-10)$ in buffers mentioned above without substrate for $30 \mathrm{~min}$. Then the enzyme was reacted with $1 \%(\mathrm{w} / \mathrm{v})$ gelatinized sagoo starch in optimum temperature and $\mathrm{pH}$. The remaining activity of the enzyme was assayed by the standard assay method (Goel and Nene 1995).

Time Course B-CD Production. After the optimum $\mathrm{pH}$ and temperature were determined, 0.001 UA enzyme was reacted with $1 \%(\mathrm{w} / \mathrm{v})$ gelatinized and raw sagoo starch in optimum $\mathrm{pH}$ and temperature for 0.5-72 $\mathrm{h}$. The $\beta$-cyclization activities were measured with the standard assay as mentioned above.

Product Specificity. 0.029 UA enzyme was reacted with $1 \%(\mathrm{w} / \mathrm{v})$ gelatinized sagoo starch in optimum $\mathrm{pH}$, temperature and incubation time. The cyclization ratio of different $\mathrm{CDs}$ produced was analyzed using HPLC with refractive index detector and $\mathrm{NH}_{2}$ column (Waters, Sperisorb). The flow was set at $1 \mathrm{~mL} / \mathrm{min}$ with $70: 30$ acetonitrile-water as mobile phase (Kinalekar et al. 2000).

Small Scale $\boldsymbol{\beta}$-CD Production. The $\beta-C D$ was produced in $100 \mathrm{~mL}$ reaction containing $0.15 \mathrm{UA}$ rCGtase and $1 \%(\mathrm{w} / \mathrm{v})$ gelatinized sagoo starch in optimum $\mathrm{pH}$, temperature and incubation time. The $\beta$ CD was measured by phenolphtalein method (Goel and Nene 1995).

\section{RESULTS}

In order to find the best growth condition for rCGTase production, optimization was done using three growth media (LB, TB, and SOB) and two temperatures (16 and $25^{\circ} \mathrm{C}$ ) were used for induction. In all media and both temperatures, rCGTase demonstrated as a 76.39 $\mathrm{kDa}$ protein was produced but at different level. The highest level was obtained when LB medium was used

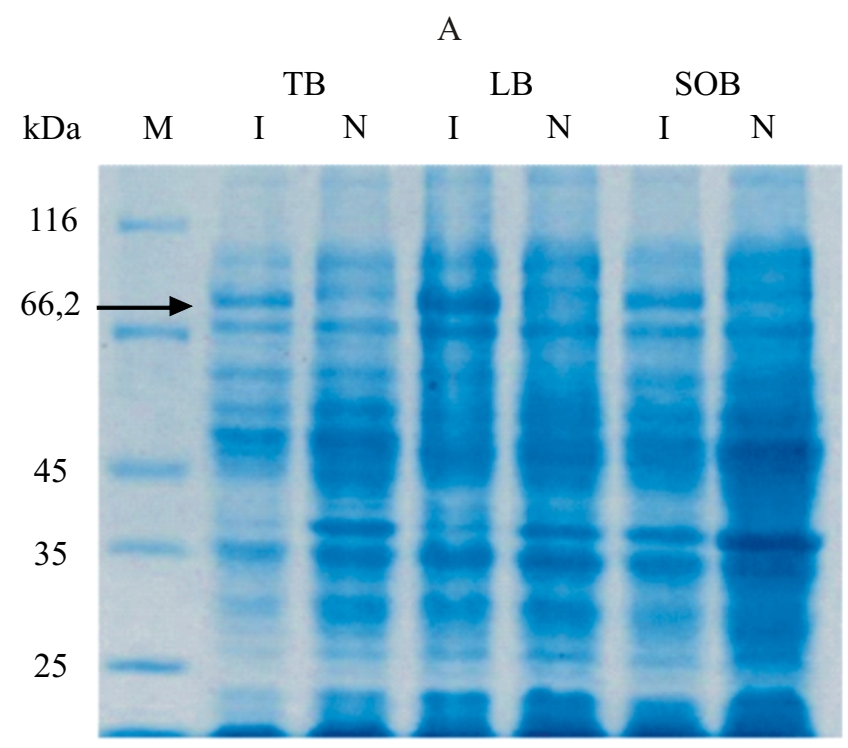

B

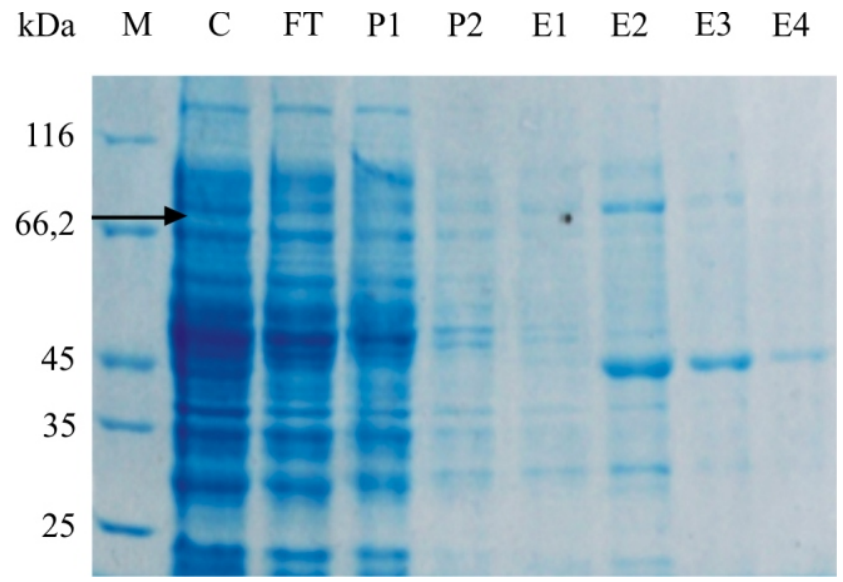

Fig 1 10\% SDS-PAGE analysis of rCGTase in overproduction and purification. (A) rCGtase overproduction using LB medium at $25{ }^{\circ} \mathrm{C}$ for $6 \mathrm{~h}$. (B) Purified rCGTase. M; protein marker; N: no IPTG induction; I: IPTG induction; TB: Terrific Broth; LB: Luria Bertani; SOB: Super Optimum Broth; C: crude extract; FT: flowthrough; W: wash; E: elution. The arrow showed rCGTase protein band.

and induction was carried out at $25^{\circ} \mathrm{C}$ for $6 \mathrm{~h}$ (Fig 1A). For further experiment, the overproduction of rCGtase was carried out using LB medium and induction was done at $25^{\circ} \mathrm{C}$ for $6 \mathrm{~h}$.

For enzyme characterization, rCGTase was required in the purified form. The rCGTase was copurified with a $45 \mathrm{kDa}$ protein (Fig 1B), identified previously as LacI protein. $8 \mathrm{~mL}$ of partially purified rCGTase in concentration $0.038 \mu \mathrm{g} \mathrm{mL}^{-1}$ was produced from $4 \times 250 \mathrm{~mL}$ culture. The $76.39 \mathrm{kDa}$ protein displayed both starch hydrolysis and $\beta$-cyclization activities as determined by zymography method (Fig 2). This demonstrated that the rCGTase produced in this 

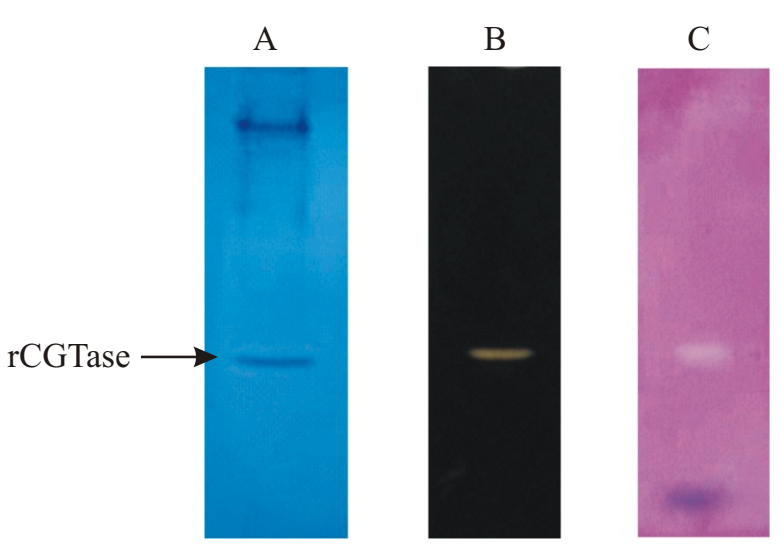

Fig 2 Result of zymography assay. (A) Coomassie blue staining. (B) $\mathrm{KI} / \mathrm{I}_{2}$ staining. (C) Phenolphtalein staining.

work was active. Although the purified rCGtase was still contaminated with LacI, there was only rCGtase band that showed hydrolysis and $\beta$-activity.

Our previous work showed that sagoo starch was the best substrate for CGTase of Bacillus sp A2-5a. The characteristic of this CGTase using sagoo starch as substrate has not been reported previously. Therefore, this current work focused on the partial characterization the enzyme using sagoo starch. The first character to be studied was its optimum temperature and its thermostability. The purified rCGtase exhibited the highest $\beta$-cyclization activity at $55{ }^{\circ} \mathrm{C}$ (Fig 3A). The activity increased from $26^{\circ} \mathrm{C}$ to $55^{\circ} \mathrm{C}$, decreased above $50{ }^{\circ} \mathrm{C}$ and was almost no activity $(10 \%)$ at $80^{\circ} \mathrm{C}$. However, it displayed $90 \%$ activity at $50-60{ }^{\circ} \mathrm{C}$ (Fig $3 \mathrm{~A})$. In terms of its thermostability, the temperature half life $\left(\mathrm{T}_{50}\right)$ was shown to be $56{ }^{\circ} \mathrm{C}$ for $30 \mathrm{~min}$ incubation (Fig 3B). rCGTase exhibited biphasic phenomenon of its activity with two optimum pHs, $\mathrm{pH} 6$ and pH 9 (Fig 3C). It displayed no activity at $\mathrm{pH} 4$ but then its activity increased and reached the first optimum $\mathrm{pH}$, at $\mathrm{pH} 6$. From $\mathrm{pH} 6$ to $\mathrm{pH} 8$, its activity declined and reached the lowest activity (about 60\%) in the range at $\mathrm{pH} 8$. With regards to its $\mathrm{pH}$ stability, rCGTase retained its activity $(>80 \%)$ at wide range of $\mathrm{pHs}(5-10)$ (Fig 3D).

The production of $\beta-\mathrm{CD}$ in the gelatinized starch was maximum at $24 \mathrm{~h}$, rCGtase did not show $\beta$ cyclization activity for raw sagoo starch (Fig 4A). But using gelatinized sagoo starch, the $\beta$-CD produced per min was highest at $30 \mathrm{~min}$ incubation and reduced considerably until $72 \mathrm{~h}$ incubation (Fig 4B). The ratio of $\alpha, \beta$, and $\gamma$-CD using $1 \% \mathrm{w} / \mathrm{v}$ gelatinized sagoo starch was $4: 81: 15$, respectively, while using $10 \%$ $\mathrm{w} / \mathrm{v}$ raw sagoo starch was $5.3: 76.4: 18.3$. In terms of $\beta$-CD production, $542 \mathrm{mg}$ was produced in $100 \mathrm{~mL}$ reaction using $1 \% \mathrm{w} / \mathrm{v}$ gelatinized sagoo starch and
0.15 UA rCGtase at optimum $\mathrm{pH}$, temperature and incubation time.

\section{DISCUSSION}

In present work, we reported better rCGTase overproduction condition and some characters of the rCGTase that are central to its use in the $\beta-C D$ production using sagoo starch. Induction at $25^{\circ} \mathrm{C}$ for 6 $\mathrm{h}$ in LB medium was the best condition for rCGTase overproduction using the starch. A number of characteristic of rCGTase of Bacillus sp. A5-2a including its optimal temperature and $\mathrm{pH}$, its thermostability and $\mathrm{pH}$ stability demonstrated that this enzyme has good thermostability and works at quite wide range of pHs. Using gelatinized sagoo starch as substrate, the enzyme maintains its product specificity with $\beta-C D$ as a predominant product and in $100 \mathrm{~mL}$ of culture, the amount of $\beta$-CD produced in optimal condition was $524 \mathrm{mg}$. The enzyme is unable to act on raw starch and then gelatinized sagoo starch should be used for the $\beta-C D$ production.

rCGTase was formed in the cytoplasm of E. coli in the form inclusion body. In this present work, induction was performed at $16{ }^{\circ} \mathrm{C}$ in attempt to obtain higher amount of soluble rCGtase. Our current result showed that the yield of soluble rCGTase was the same as that of previous work at $25{ }^{\circ} \mathrm{C}$ and the yield of the total rCGtase, in the form of soluble and inclusion body was the highest using LB as growth medium.

Optimum temperature and thermostability. The optimum temperature of rCGtase using sagoo starch was the same as that of native CGtase A2-5a (Komentani et al. 1994) and rCGTase A2-5a in B. subtilis ANA-1 (Ohdan et al. 2000), ranging of 50-55 ${ }^{\circ} \mathrm{C}$. The $\mathrm{T}_{50}$ of rCGtase using sagoo starch $\left(56^{\circ} \mathrm{C}\right)$ was lower than native CGTase A2-5a $\left(64.4^{\circ} \mathrm{C}\right.$ ) (Kelly et al. 2009). The difference was probably due to the presence of $\mathrm{CaCl}_{2}$ in the assay activity of native CGTase A2-5a (Kelly et al. 2009). Moreover, in this research the reaction was done at $\mathrm{pH} 7.0$, while the $\mathrm{pH}$ stability assay of native CGTase A2-5a was carried out at $\mathrm{pH} 5.5$ which was close to optimum $\mathrm{pH}$ of rCGtase at $\mathrm{pH} 6$.

Optimum $\mathrm{pH}$ and $\mathrm{pH}$ Stability. The $\mathrm{pH}$ optimum of rCGtase using sagoo starch ( $\mathrm{pH}$ 6.0) as substrate was slightly different from native CGTase A2-5a (pH 5.5) (Ohdan et al.2000). The difference of optimum $\mathrm{pH}$ was probably caused by the difference of incubation temperature. In this research, the incubation temperature was at $55{ }^{\circ} \mathrm{C}$ while native CGTase A2-5a was at $40^{\circ} \mathrm{C}$. The CGTase which has optimum activity 

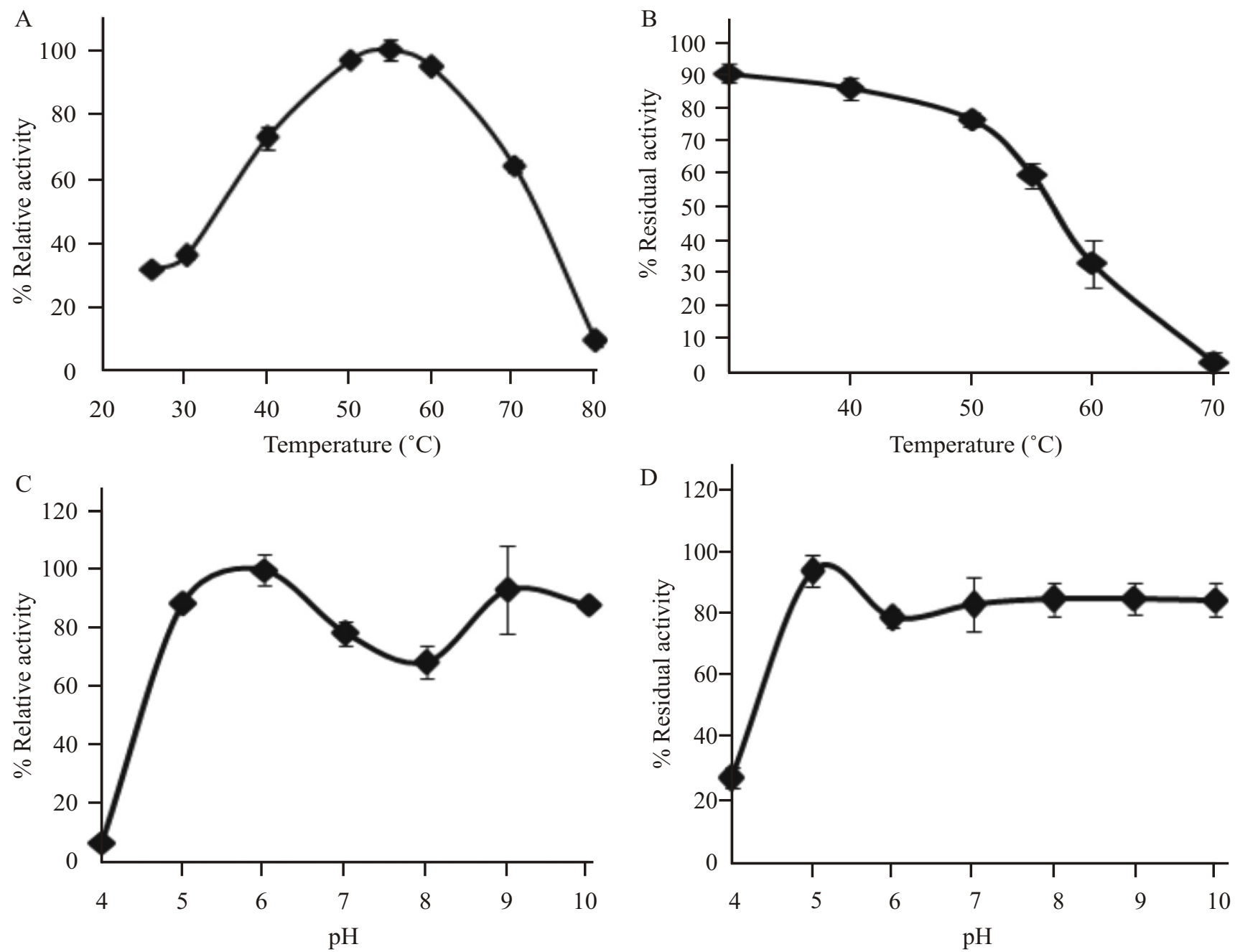

Fig 3 Properties of the purified rCGTase A2-5a using sagoo starch as substrate. (A) Temperature profile of purified rCGTase. For this temperature profile, enzymatic activity was measured in Tris- $\mathrm{Cl} \mathrm{pH} \mathrm{7.0.} \mathrm{(B)} \mathrm{Thermal} \mathrm{stability} \mathrm{of} \mathrm{purified}$ rCGTase. Thermostability was determined by preincubating the enzyme in Tris- $\mathrm{Cl} \mathrm{pH} 7.0$ at designed temperatures for 30 min. (C) pH profile purified rCGTase. The reaction $\mathrm{pHs}$ were adjusted to 4-10 with the following buffers: Na-acetat ( $\mathrm{pH}$ 4.0-5.0), Na-phosphate ( $\mathrm{pH}$ 6.0-8.0), and Glycine-NaOH (pH 9.0-10.0). (D) $\mathrm{pH}$ stability purified rCGTase. $\mathrm{pH}$ stability was determined by preincubating enzyme at following buffer Na-acetat (pH 4.0-5.0), Na-phosphate (pH 6.08.0), and Glycine- $\mathrm{NaOH}$ ( $\mathrm{pH} 9.0-10.0$ ) for $30 \mathrm{~min}$. The given values in all activity assays are the means of triplicates, and the error bars indicate the standard deviation of these triplicates of independent experiment
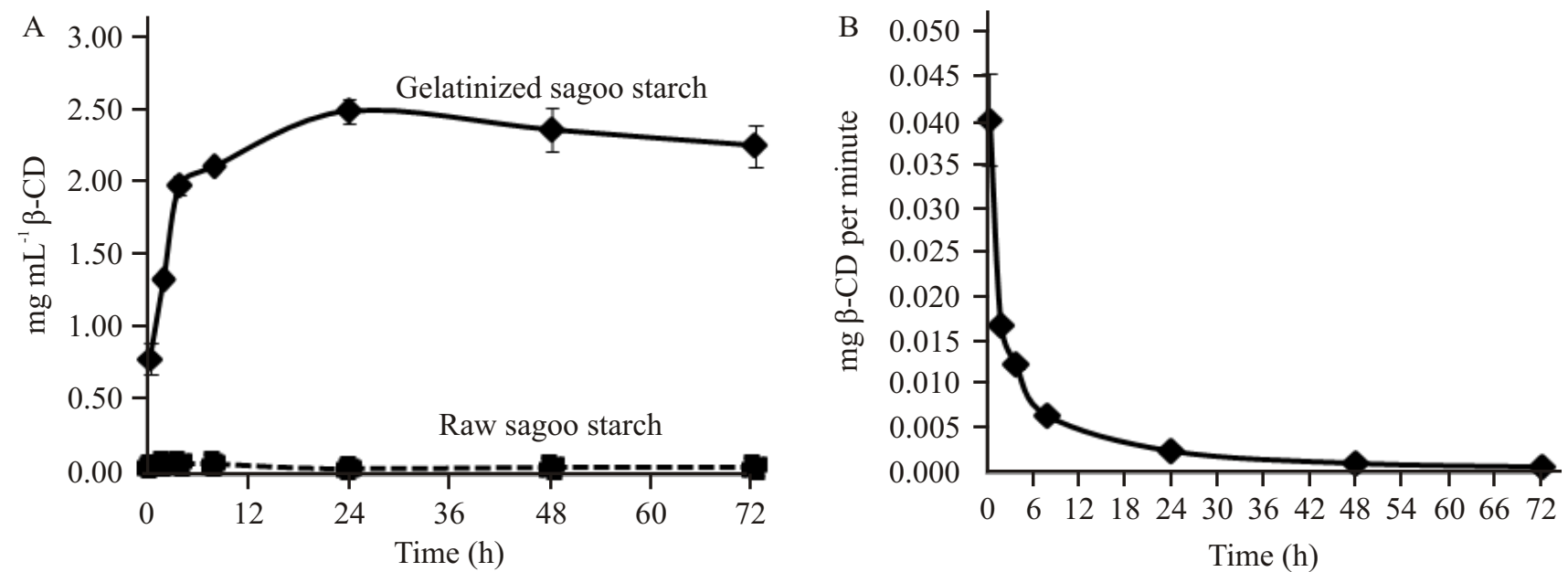

Fig 4 Time course of $\beta$-CD production using purified rCGTase Bacillus sp. A2-5a using 1\% (w/v) gelatinized sagoo starch as substrate. The reaction was carried out at $55^{\circ} \mathrm{C}$ in $100 \mathrm{~mL}$ of $50 \mathrm{mM}$ phosphate buffer $\mathrm{pH}$ 6.0. (A) amount $\beta$-CD produced during $72 \mathrm{~h}$. (B) $\mathrm{mg} \beta-\mathrm{CD}$ produced per min during $72 \mathrm{~h}$. 
at $\mathrm{pH} 6$ is from Bacillus sp. TS1-1, G1 and 17-1 (Rahman et al. 2006; Ong et al. 2008; Kaneko et al. 1989). rCGTase retained $>50 \%$ of its activity at $\mathrm{pHs}$ 5.0-10.0, while native CGTase A2-5a retains $50 \%$ of its activity at pHs 9.0-10.0 (Komentani et al. 1994).

Time course experiment of $\beta-C D$ production. rCGtase using sagoo starch produced maximum $\beta-C D$ at $24 \mathrm{~h}$ reaction time, in contrast, the $\beta-\mathrm{CD}$ produced per minute was highest at $30 \mathrm{~min}$ incubation time. It showed that the activity of the rCGtase decreased in longer period of reaction. In CDs ratio assay using $1 \%$ (w/v) gelatinized sagoo starch, the $\alpha, \beta$, and $\gamma$-CD ratio was $4: 81: 15$, respectively. The $\alpha, \beta$, and $\gamma$-CD ratio from native rCGTase is $5: 77: 18$ (Kelly et al. 2009), respectively and $\beta-C D$ was still the predominant product. In other research using CGTase from Bacillus circulans and sagoo starch as substrate, $\beta-\mathrm{CD}$ is $65 \%$ from total CDs produced (Charoenlap et al. 2004). The $5.42 \pm 0.75 \mathrm{~g} \mathrm{~L}^{-1} \beta-\mathrm{CD}$ produced from $100 \mathrm{~mL}$ reaction at optimum condition had not purified yet.

In conclusion, the difference of substrate did not influence of some characteristics of rCGTase A2-5a such as optimum temperature and $\mathrm{pH}$ but the $\beta-\mathrm{CD}$ yield was higher when using sagoo starch as substrate than using soluble starch. Further study of the rCGTase and $\beta-C D$ production followed by $\beta-C D$ purification should be done in the near future to obtain purified rCGTase and $\beta-C D$ in larger scale using sagoo starch; therefore their use in industrial scale can be applied.

\section{ACKNOWLEDGMENT}

We thank to Research Center for Food, Health, and Drugs of ITB for the financial support of the research.

\section{REFERENCES}

Charoenlap N, Saovanee D, Sarote S, Sittiwat L. 2004. Optimization of cyclodextrin production from sago starch. Bioresour Technol. 92(1): 49-54. doi:10.1016/j.biortech.2003.07.007.

Endo T, Ueda H. 2004. Large ring cyclodextrins-Recent progress. FABAD J Pharm Sci. 29: 27-38.
Gallagher, SR. 2010. Digital Image Processing Analysis with ImageJ. Current Protocols Essential Laboratory Technique.A.3C.1-A.3C.24. doi:10.1002/9780470089 41.eta03 $\operatorname{cs} 03$.

Goel A, Nene SN. 1995. Modifications in the phenolphthalein method for spectro-photometric estimation of beta cyclodextrin. Starch 47(10): 399-400. doi: 10.1002/star.19950471006.

Kaneko T, Song KB, Hamamoto T, Kudo T, Horikoshi K. 1989. Construction of a chimeric series of Bacillus cyclomaltodextrin glucanotransferase and analysis of the thermal stabilities and $\mathrm{pH}$ optima of the enzyme. J Gen Microbiol. 135(12): 3447-3457. doi: 10.1099/00221287135-12-3447.

Kelly R, Dijkhuizen ML, Leemhuis H. 2009. The evolution of cyclodextrin glucanotransferase product specificity. Appl Microbiol Biotechnol. 84(1): 119-133. doi: 10.1007/s00253-009-1988-6.

Kinalekar MS, Kulkarni SR, Vavia PR. 2000. Simultaneous determination of $\alpha, \beta$, and $\gamma$ cyclodextrins by LC. J Pharm Biomed Anal. 22(4): 661-666. doi: 10.1016/S0731-7085(99)00299-X.

Ohdan K, Kuriki T, Takata H, Okada S. 2000. Cloning of the cyclodextrin glukanotransferase and the impact for biotechnological applications. Appl Microbiol Biotechnol. 85: 823-835.

Ong RI, Goh KM, Mahadi NM, Hassan O, Rahman RNRZA, Illias RM. 2008. Cloning, extracellular expression and characterization of a predominant $\beta$-CGTase from Bacillus sp. G1 in E.coli. Indian J Microbiol Biotechnol. 35(12): 1705-1714. doi : 10.1007/s10295008-0462-2.

Pakzad SR, Ajdary SN, Moazami, Haghighi S. 2004. A novel method to detect $\beta$-cyclodextrin glucosyl transferase ( $\beta$-CGTase) activity on polyacrylamide gels. J Iran Biomed. 9(2): 87-90.

Rahman K, Illias RM, Hassan O, Mahmood NAN, Rashid NAA. 2006. Molecular cloning of a cyclodextrin glucanotransferase gene for alkalophilic Bacillus sp. TS1-1 and characterization of the recombinant enzyme. Enzyme Microb Technol. 39: 74-84. doi: 10.1016/j.enzmictec.2005.09.014.

Szejtli J. 1997. Utilization of cyclodextrins in industrial products and processes. J Mater Chem. 7(4): 575-587. doi: 10.1039/A605235E. 